\title{
PERTANGGUNGJAWABAN HUKUM TERHADAP PELAKU PENYIMPANAN UANG RUPIAH PALSU DIHUBUNGKAN DENGAN UNDANG-UNDANG NOMOR 7 TAHUN 2011 TENTANG MATA UANG
}

\author{
Eggi Suprayogi ${ }^{1}$ \\ Yeni Nuraeni ${ }^{2}$
}

\begin{abstract}
ABSTRAK
Masyarakat menaruh kepercayaan yang besar atas kebenaran suatu nilai mata uang, oleh karena itu atas kebenaran dari nilai mata uang harus dijamin dari pemalsuan, Namun kejahatan pemalsuan mata uang dewasa ini semakin merajalela dalam skala yang besar dan sangat merisaukan dimana dampak yang paling utama yang ditimbulkan oleh kejahatan pemalsuan mata uang ini yaitu dapat mengancam kondisi moneter dan perekonomian nasional Tujuan penelitian ini adalah Mengetahui dan memahami Proses Penegakan Hukum Terhadap Pelaku Penyebaran dan Penyimpanan Uang Rupiah.

Metode penelitian yang digunakan dalam penelitian ini adalah spesifikasi penelitian dilakukan secara deskriptif - analitis, yaitu untuk menggambarkan fakta berupa data realita lapangan menggunakan bahan primer, tersier dan sekunder yang ada di perpustakaan dan dikaitkan dengan teori-teori hukum menyangkut permasalahan yang diangkat dalam penelitian ini yaitu Penegakan Hukum Terhadap Pelaku Penyimpanan Uang Rupiah Palsu Dihubungkan Dengan Undang-Undang 7 Tahun 2011 Tentang Mata Uang Metode pendekatan yang dilakukan adalah Yuridis Empiris yang dibantu Yuridis Normatif, yaitu metode penelitian hukum ini pada dasarnya merupakan penggabungan antara pendekatan hukum normatif dengan adanya penambahan berbagai unsur empiris. Metode penelitian empiris - normatif mengenai implementasi ketentuan hukum normatif (undang - undang) dalam aksinya pada setiap peristiwa hukum tertentu yang terjadi dalam suatu masyarakat

Berdasarkan hasil penelitian diketahui bahwa Proses penegakan hukum terhadap pelaku penyebaran dan penyimpanan uang rupiah palsu di Kabupaten Majalengka dilaksanakan oleh aparat penegak hukum mulai dari kepolisian, kejaksanaan dan pengadilan, sesuai dengan tahapan sistem peradilan pidana di Indonesia, Hambatan yang ditemukan dalam penanggulangan pemalsuan mata uang dibagi atas hambatan internal dan hambatan eksternal.
\end{abstract}

Kata Kunci: Penegakan Hukum, Rupiah Palsu, Undang-Undang.

\footnotetext{
${ }^{1}$ Mahasiswa Fakultas Hukum Universitas Majalengka

${ }^{2}$ Dosen Tetap Universitas Majalengka. Email : yeninur446@gmail.com
} 
PRESUMPTION of LAW

Fakultas Hukum Universitas Majalengka

Volume 3 Nomor 2 Oktober 2021

\section{A. Latar Belakang}

Uang merupakan suatu benda yang wujudnya sedemikian rupa yang digunakan sebagai alat pembayaran yang sah dan berlaku pada saat peredarannya. Sah dalam arti yang menurut peraturan dikeluarkan oleh lembaga yang berwenang. Lembaga yang berwenang ini adalah negara atau badan yang ditunjuk oleh negara yaitu Bank Indonesia. ${ }^{3}$ Uang terdiri atas mata uang logam dan uang kertas. Adapun fungsi dari uang menurut Boediono, yaitu sebagai satuan hitung, sebagai alat transaksi, sebagaipenyimpanan nilai, dan standar pembayarandi masa depan.

Keberadaan uang sangatlah dibutuhkan dalam kegiatan manusia seharihari. Dapat diibaratkan uang sebagai jantung perekonomian dalam kehidupan masyarakat, tanpa adanya uang maka manusia tidak mampu untuk memenuhi kebutuhannya sehari-hari. Oleh karena itu, dapat dikatakan bahwa uang merupakan suatu hal yang sangat penting dalam suatu perekonomian melihat dari fungsi utamanya yaitu uang sebagai alat pembayaran.

Di era perekonomian suatu negara yang terpuruk karena krisis ekonomi yang melanda di dunia ini mengakibatkan keadaan hidup dan kebutuhan hidup manusia dirasa sangat menghimpit. Peran uang yang begitu pentingnya telah menumbuhkan keinginan manusia untuk memiliki uang sebanyak-banyaknya dan tidak jarang cara-cara untuk memperoleh uang dilakukan dengan melawan hukum, mengingat di dalam masyarakat modern, dimana mekanisme perekonomian didasarkan pada lalu lintas barang dan jasa, semua kegiatankegiatan ekonomi yang dilakukan akan memerlukan uang sebagai alat pelancar guna mencapai tujuannya.

Uang merupakan bagian yang tidak bisa dipisahkan dari denyut kehidupan ekonomi masyarakat. Stabilitas ekonomi dan pertumbuhan ekonomi suatu negara ditentukan oleh sejauh mana peranan uang dalam perekonomian oleh masyarakat dan otoritas moneter. Uang adalah suatu benda yang dipergunakan oleh umum sebagai alat perantara untuk mempermudah proses pertukaran. Atau dengan kata-kata lain dapat pula dinyatakan bahwa uang mungkin didefinisikan sebagai suatu benda yang diterima sebagai pembayaran penuh untuk suatu barang atau jasa, dari seseorang yang mungkin tidak dan belum dikenal.

Mengingat fungsi uang yang sangat vital sebagai alat pembayaran, maka tindak pidana pemalsuan uang berdampak besar dan merugikan negara. Dampak pemalsuan dan peredaran uang palsu adalah dapat menurunkan kepercayaan masyarakat terhadap mata uang yang dicetak Bank Indonesia. Uang palsu merupakan hasil perbuatan tindak pidana melawan hukum berupa meniru dan/atau memalsukan uang yang dikeluarkan sebagai satuan mata uang yang sah. Pemalsuan uang mengandung nilai ketidak benaran atau palsu atas sesuatu atau objek, di mana sesuatu nampak dari luar seolah-olah benar adanya, namun sesungguhnya bertentangan dengan yang sebenarnya. Tindak pidana pemalsuan uang merupakan kejahatan yang memanfaatkan kemajuan

${ }^{3}$ Adami Chazawi, Kejahatan Mengenai Pemalsuan, Raja Grafindo Persada, Jakarta, 2005, hlm. 26. 
PRESUMPTION of LAW Fakultas Hukum Universitas Majalengka

ilmu pengetahuan dan teknologi, karena para pelaku tindak pidana pemalsuan uang ini pada umumnya memiliki kemampuan dan keahlian khusus di bidang program komputer maupun teknik percetakan.

Pemalsuan uang merupakan salah satu bentuk perbuatan yang disebut sebagai kejahatan yaitu sebagai suatu perbuatan yang sifatnya bertentangan dengan kepentingan hukum. Sebab dan akibat dari kejahatan itu menjadi perhatian utama dari berbagai pihak, dengan mengadakan penelitian-penelitian berdasarkan metode-metode ilmiah agar diperoleh suatu kepastian untuk menetapkan porsi dan klasifikasi dari kejahatan tersebut.

Pemalsuan uang merupakan bentuk kejahatan yang masih kurang dipahami oleh masyarakat oleh karena itu masih ditemukannya pemalsuan uang di kalangan masyarakat. Hal ini disebabkan kurangnya sosialisasi aparat penegak hukum dan masih rendahnya pemahaman masyarakat tentang akibat yang ditimbulkan dari pemalsuan uang tersebut

Pemalsuan merupakan suatu kejahatan yang di atur dalam KUHPidana, dimana tindak pidana pemalsuan uang dan uang kertas di atur dalam Pasal 244 sampai dengan Pasal 252 KUHPidana. Tindak pidana peniruan dan pemalsuan mata uang dan uang kertas yang disingkat dengan pemalsuan uang menurut Adami Chazawi adalah "berupa penyerangan terhadap kepentingan hukum atas kepercayaan terhadap uang sebagai alat pembayaran yang sah".

Tindak pidana pemalsuan uang mengalami perkembangan yang cukup kompleks karena memiliki dimensi yang luas dan saling berkaiatan, di antaranya adalah pelaku pemalsuan uang yang melibatkan para pelaku yang lebih dari satu orang, modus pemalsuan uang, motivasi dan faktor pendukung pemalsuan uang dan wilayah pemalsuan dan peredaran uang palsu yang luas. Selain itu, karena objek yang dipalsukan adalah uang sebagai alat pembayaran sah pada suatu negara maka akan berdampak negatif pada perekonomian suatu negara.

Masyarakat menaruh kepercayaan yang besar atas kebenaran suatu nilai mata uang, oleh karena itu atas kebenaran dari nilai mata uang harus dijamin dari pemalsuan. Penyerangan terhadap kepercayaan atas kebenarannya adalah perbuatan yang patut dipidana, yang oleh undang-undang ditentukan sebagai suatu kejahatan. Namun kejahatan pemalsuan mata uang dewasa ini semakin merajalela dalam skala yang besar dan sangat merisaukan dimana dampak yang paling utama yang ditimbulkan oleh kejahatan pemalsuan mata uang ini yaitu dapat mengancam kondisi moneter dan perekonomian nasional. Tindak pidana pemalsuan uang tidak hanya terjadi pada saat masa sekarang ini tetapi sudah terjadi sejak masa lampau, ${ }^{5}$ Untuk menyadarkan kesadaran hukum pelaku tersebut maka haruslah dikenakan sanksi yang mengatur tentang tindak pidana tersebut. Sanksi terhadap uang palsu selain d atur dalam KUHP dan juga diatur di luar Kitab Undang-Undang Hukum Pidana (KUHP) yaitu dalam Undang-

\footnotetext{
${ }^{4}$ Ibid hlm 100.
}

${ }^{5}$ Agus Triboyono, Peranan Kepolisian Satuan Reserse Kriminal Dalam Pemberantasan Peredaran Uang Palsu Di Wilayah Kepolisian Resor Labuhanbatu Berdasarkan UndangUndang Nomor 7 Tahun 2011 Tentang Mata Uang, JOM Fakultas Hukum Volume III Nomor 2, Oktober 2016, hlm 2 
PRESUMPTION of LAW

Fakultas Hukum Universitas Majalengka

Volume 3 Nomor 2 Oktober 2021

Undang Nomor 7 Tahun 2011 tentang Mata Uang pada Pasal 36 yang memuat ketentuan pidana terhadap uang palsu.

Penerapan berat ringannya pidana yang dijatuhkan tentu bagi seorang hakim disesuaikan dengan apa yang menjadi motivasi dan akibat perbuatan si pelaku, khususnya dalam penerapan jenis pidana penjara, namun dalam hal Undang-undang tertentu telah mengatur secara normatif tentang pasal-pasal tertentu tentang pemidanaan dengan ancaman minimal seperti diatur dalam Undang-Undang. Bagii masyarakat, kepercayaan terhadap lembaga peradilan sangat diperlukan untuk menghindari tindakan main hakim sendiri, serta untuk menciptakan ketertiban hukum. Sedangkan bagi lembaga peradilan, kepercayaan masyarakat sangat penting, tidak hanya sebagai wujud apresiasi atas pertanggungjawaban hakim tetapi juga memberikan suasana nyaman dan kondusif bagi kinerja peradilan dan membangun kewibawaan peradilan sehingga akhirnya mendekatkan pada keinginan kita bersama untuk mewujudkan peradilan yang bersih dan bermartabat.

Berdasarkan latar belakang diatas maka saya dituangkan ke dalam penelitia dengan judul “ Pertanggungjawaban Hukum Terhadap Pelaku Penyimpanan Uang Rupiah Palsu Dihubungkan Dengan UndangUndang 7 Tahun 2011 Tentang Mata Uang”.

\section{B. Identifikasi Masalah}

Berdasarkan uraian latar belakang penelitian ini, penulis membatasi ruang lingkup penelitian ini dengan beberapa Identifikasi Masalah sebagai berikut :

1. Bagaimanakah Proses Penegakan Hukum Terhadap Pelaku Penyebaran dan Penyimpanan Uang Rupiah Palsu?

2. Apa Sajakah Yang Menjadi Hambatan Dalam Penegakan Hukum Terhadap Pelaku Penyebaran dan Penyimpanan Uang Rupiah Palsu?

3. Bagaimana upaya pemerintah dalam mengatasi masalah penyebaran uang palsu?

\section{Tujuan Penelitian}

Kegiatan penelitian pasti terdapat suatu tujuan yang jelas. Tujuan penelitian ini adalah untuk memberi arah dalam melangkah sesuai dengan maksud penelitian. Adapun tujuan yang ingin dicapai oleh penulis dalam peneltian ini adalah:

1. Mengetahui dan memahami Proses Penegakan Hukum Terhadap Pelaku Penyebaran dan Penyimpanan Uang Rupiah Palsu

2. Mengetahui dan memahami Hambatan Dalam Penegakan Hukum Terhadap Pelaku Penyebaran dan Penyimpanan Uang Rupiah Palsu

3. Mengetahui dan memahami upaya pemerintah dalam mengatasi masalah penyebaran Uang Palsu. 


\section{Metode Penelitian}

Metode penelitian yang digunakan dalam penelitian ini dengan menggunakan metode deskriptif analitis yaitu memberikan gambaran yang relevan tentang sifat atau karakteristik suatu keadaan permasalahan dalam penelitian untuk kemudiaan dianalisis berdasarkan teori-teori hukum dan praktek pelaksanaan hukum positif yang menyangkut permasalahan pada umumnya. Dan metode pendekatan yang digunakan dalam penelitian ini adalah metode pendekatan yuridis empiris, yaitu suatu pendekatan yang meneliti data sekunder terlebih dahulu dan kemudian dilanjutkan dengan mengadakan penelitian data primer di lapangan. Data sekunder yang dimaksud di sini adalah landasan teoritis berupa pendapat atau tulisan-tulisan para ahli atau pihak lain yang berwenang dan informasi-informasi lain yang berupa ketentuan-ketentuan formal seperti peraturan perundang-undangan, putusan pengadilan, dan lainlain, sedangkan data primer dalam penelitian ini adalah hasil dari penelitian lapangan seperti wawancara. Jelas metode pendekatan yang digunakan dalam penelitian ini adalah metode pendekatan secara yuridis empiris.

\section{E. Hasil Penelitian dan Pembahasan}

\section{Proses Penegakan Hukum Terhadap Pelaku Penyebaran dan Penyimpanan Uang Rupiah Palsu}

Penegakan hukum dapat menjamin kepastian hukum, ketertiban dan perlindungan hukum pada era modernisasi dan globalisasi saat ini dapat terlaksana, apabila berbagai dimensi kehidupan hukum selalu menjaga keselarasan, keseimbangan dan keserasian antara moralitas yang didasarkan oleh nilai-nilai aktual di dalam masyarakat beradab. Sebagai suatu proses kegiatan yang meliputi berbagai pihak termasuk masyarakat dalam kerangka pencapaian tujuan penegakan hukum pidana sebagai sistem peradilan pidana $^{6}$ yaitu: ${ }^{7}$

Penegakan hukum sendiri harus diartikan dalam kerangka tiga konsep,

1. Konsep penegakan hukum yang bersifat total (total enforcement concept)

2. Konsep penegakan hukum yang bersifat penuh (full enforcement concept)

3. Konsep penegakan hukum aktual (actual enforcement concept)

Hal yang mendasari penegakan hukum adalah pemahaman bahwa setiap manusia dianugerahi Tuhan Yang Maha Esa dengan akal budi dan nurani yang memberikan kepadanya kemampuan untuk membedakan yang baik dan yang buruk yang akan membimbing dan mengarahkan sikap dan perilaku dalam menjalani kehidupannya. Dengan akal budi dan nuraninya itu, maka manusia memiliki kebebasan untuk memutuskan sendiri perilaku

${ }^{6}$ Suhendar Herdiyansyah dan Cecep Sutrisna, Penegakan Hukum Terhadap Tindak Pidana Kepabeanan Atas Implikasi Penyelundupan Barang Ekspor Dihubungkan Dengan Undang-Undang No 17 Tahun 2006 Tentang Kepabeanan, Vol 17 No 1 (2018): Wacana Paramarta: Jurnal Ilmu Hukum XVII:1:2018, hlm 62, file:///C:/Users/MINI\% 20PC/ Downloads/ 56-Article\%20Text-337-1-10-20200623.pdf diakses pada tanggal 29 Juni 2021.

${ }^{7}$ Ibid 
atau perbuatannya. Selain untuk mengimbangi kebebasan tersebut, manusia memiliki kemampuan untuk bertanggung jawab atas semua tindakan yang dilakukannya di hadapan hukum yang diakui bersama.

Negara Indonesia adalah negara hukum (recht staats), maka setiap orang yang melakukan tindak pidana harus mempertanggung jawabkan perbuatannya melalui penegakan hukum. Hukum dalam hal ini merupakan sarana bagi penegakan hukum. Penegakan hukum mengandung makna bahwa tindak pidana adalah suatu perbuatan yang dilarang oleh suatu aturan hukum, dimana larangan tersebut disertai dengan ancaman (sanksi) yang berupa pidana tertentu sebagai pertanggung jawabannya.

Kejahatan pemalsuan uang merupakan kejahatan yang mana di dalamnya mengandung sistem ketidakbenaran atau palsu sesuatu (objek) yang sesuatunya itu tampak dari luar seolah-olah benar adanya, padahal sesungguhnya bertentangan dengan yang sebenarnya. Jadi secara umum tindak pidana pemalsuan uang adalah kegiatan menirukan keaslian dari suatu nilai mata uang yang didalamnya mengandung ketidakbenaran untuk diedarkan luas di masyarakat. ${ }^{8}$

Uang palsu adalah hasil perbuatan tindak pidana melawan hukum berupa meniru dan/atau memalsukan uang yang dikeluarkan sebagai satuan mata uang yang sah. Kejahatan pemalsuan uang rupiah merupakan kejahatan yang serius karena selain bertujuan untuk memperkaya diri sendiri secara ekonomis, juga bertujuan untuk menghancurkan perekonomian negara secara politis. Kejahatan tersebut juga semakin canggih karena kemajuan dan kebaruan teknologi. Tanggung jawab terhadap kejahatan pemalsuan uang rupiah tentu saja bukan tugas dari Bank Indonesia dan pihak kepolisian semata, melainkan tugas dari seluruh lapisan masyarakat untuk secara bersama-sama memerangi kejahatan tersebut. Untuk mengamankan uang rupiah, maka dalam rangka melakukan pemberantasan terhadap peredaran uang rupiah palsu, masyarakat secara langsung perlu dilibatkan untuk turut berperan aktif dalam menanggulangi nya.

Mengingat semua kegiatan transaksi ekonomi di suatu negara, keberadaan uang palsu merupakan suatu hal yang sulit untuk dihindari, karena uang memiliki fungsi yang strategis dalam kelangsungan suatu pemerintahan atau negara. Sifat strategis tersebut disebabkan karena selain uang dapat dijadikan sebagai alat transaksi untuk memenuhi kebutuhan ekonomi masyarakat, uang juga dapat dijadikan sebagai alat politik untuk menjatuhkan perekonomian suatu negara.

Agar keberadaan uang di suatu negara tetap selalu dalam fungsinya sesuai dengan tujuannya, maka pencegahan uang palsu perlu diupayakan baik secara preventif maupun represif. Pemalsuan uang dilatarbelakangi oleh situasi perekonomian yang terpuruk, menyebabkan banyak masyarakat yang ingin mendapatkan uang banyak untuk memenuhi kebutuhan hidupnya

${ }^{8}$ Erna Dewi , Penegakan Hukum Terhadap Pelaku Tindak Pidana Pemalsuan Uang Dan Pengedar Uang Palsu Di Kota Bandar Lampung, Keadilan Progresif, Fakultas Hukum Universitas lampung Volume 5 Nomor 1 Maret 2014, hlm 75. 
PRESUMPTION of LAW

Fakultas Hukum Universitas Majalengka

Volume 3 Nomor 2 Oktober 2021

dengan cara yang mudah. Hal itu menjadi salah satu motivasi yang kuat bagi para pemalsu dalam melakukan perbuatannya, di samping motivasi lainnya seperti motivasi politis untuk mengacaukan perekonomian negara.

Berdasarkan uraian di atas maka dapat dinyatakan bahwa untuk menanggulangi kejahatan mata uang, dari segi hukum material yang berlaku saat ini sebenarnya sudah cukup mengantisipasi kejahatan mata uang baik yang terdapat dalam KUHP maupun di luar KUHP. Akan tetapi dari segi hukum formal perlu memperhatikan beberapa hal yang berkaitan dengan profesionalisme aparat, sarana dan prasarana. Dalam rangka penanggulangan preventif kejahatan mata uang,khususnya yang berkaitan dengan pemalsuan dan pengedarannya, Bank Indonesia adalah institusi yang memegang peranan penting. Sebab, yang berhak dan mempunyai kewenangan penuh untuk menentukan palsu atau tidaknya uang yang beredar adalah Bank Indonesia.

Memenuhi kebutuhan akan uang, pemerintah Negara yang bersangkutan melalui bank sentral berhak menciptakan uang, terutama uang kartal. Begitu pula dengan jumlah uang yang beredar perlu dijaga agar nilai uang tetap tetap stabil. Kemudian kebutuhan akan uang giral biasanya di cetak oleh bank-bank umum dimana jumlahnya jauh melebihi jumlah uang kartal yang beredar. Dalam hal berkaitan dengan uang maka peranan lembaga keuangan terutama bank sangatlah besar, hal ini sesuai dengan fungsi lembaga keuangan yaitu sebagai perantara keuangan di masyarakat. Oleh karena itu di banyak negara, pengaturan tentang mata uang ini dimuat di dalam konstitusi (Undang-Undang Dasar) dari negara yang bersangkutan. Di Indonesia, ketentuan tentang mata uang ini dimuat di dalam Pasal 23 ayat (3) Undang-Undang Dasar Negara Republik Indonesia Tahun 1945 (UUD 1945 sebelum amandemen) yang menentukan bahwa: "Macam dan harga mata uang ditetapkan dengan Undang-Undang". Ketentuan yang sama diatur kembali dalam Pasal 23B UUD 1945 setelah amandemen keempat.

Kejahatan pemalsuan uang merupakan kejahatan yang serius karena selain bertujuan untuk memperkaya diri sendiri secara ekonomis, dapat berdampak pada menurunnya kestabilan perekonomian negara. Kejahatan tersebut juga semakin canggih karena kemajuan dan kebaruan teknologi. Tanggung jawab terhadap kejahatan pemalsuan uang Rupiah tentu saja bukan tugas dari Bank Indonesia dan pihak kepolisian semata, melainkan tugas dari seluruh lapisan masyarakat untuk secara bersama-sama memerangi kejahatan tersebut.

Hukum positif yang mengatur tentang aspek-aspek mata uang dan kejahatan terhadap mata uang diantaranya terdiri, yaitu Undang-Undang Nomor 23 Tahun 1999 Tentang Bank Indonesia sebagaimana telah diubah dengan Kitab Undang-Undang Hukum Pidana (KUHP), Undang-Undang Nomor 3 Tahun 2004 dan Undang-Undang No. 7 Tahun 2011 tentang Mata Uang, Pengaturan tentang mata uang dalam hukum positif yang berlaku saat ini secara ringkas adalah: 
PRESUMPTION of LAW

Fakultas Hukum Universitas Majalengka

Volume 3 Nomor 2 Oktober 2021

1. Pengaturan dalam Undang-Undang Nomor 23 Tahun 1999 tentang Bank Indonesia yaitu pada Pasal-Pasal 2, 3, 19 s.d 23, serta 65 dan 66 sebagai berikut:

a. Pasal 2 Undang-Undang Nomor 23 Tahun 1999 tentang Bank Indonesia. Mengatur mengenai (1) Satuan mata uang negara Republik Indonesia adalah rupiah dengan singkatan Rp. (2) Uang rupiah adalah alat pembayaran yang sah di wilayah negara Republik Indonesia. (3) Setiap perbuatan yang menggunakan uang atau mempunyai tujuan pembayaran atau kewajiban yang harus dipenuhi dengan uang jika dilakukan di wilayah negara Republik Indonesia wajib menggunakan uang rupiah, kecuali apabila ditetapkan lain dengan Peraturan Bank Indonesia. (4) Setiap orang atau badan yang berada di wilayah negara Republik Indonesia dilarang menolak untuk menerima uang rupiah yang penyerahannya dimaksudkan sebagai pembayaran atau memenuhi kewajiban yang harus dipenuhi dengan uang sebagaimana dimaksud pada ayat (3).

b. Pasal 3, ayat (1) Undang-Undang Nomor 23 Tahun 1999 tentang Bank Indonesia, mengatur tentang larangan pembawaan uang rupiah dalam jumlah tertentu ke luar atau masuk wilayah pabean.

c. Pasal-pasal 19, 21, 20, 22 dan 23 Undang-Undang Nomor 23 Tahun 1999 tentang Bank Indonesia, mengatur mengenai kewenangan BI. Dalam Pasal 19 Undang-Undang Nomor 23 Tahun 1999 tentang Bank Indonesia menyatakan bahwa Bank Indonesia berwenang menetapkan macam, harga, ciri uang yang akan dikeluarkan, bahan yang digunakan dan tanggal mulai berlakunya sebagai alat pembayaran yang sah. Pasal 20 Undang-Undang Nomor 23 Tahun 1999 tentang Bank Indonesia menyatakan bahwa Bank Indonesia merupakan satusatunya lembaga yang berwenang untuk mengeluarkan dan mengedarkan uang rupiah serta mencabut, menarik dan memusnahkan uang dimaksud dari peredaran. Pasal 21 Undang-Undang Nomor 23 Tahun 1999 tentang Bank Indonesia menyatakan bahwa ang yang dikeluarkan oleh Bank Indonesia dibebaskan dari bea meterai.

Pasal 22 Undang-Undang Nomor 23 Tahun 1999 tentang Bank Indonesia menyatakan bahwa Bank Indonesia tidak memberikan penggantian atas uang yang hilang atau musnah karena sebab apapun.

Pasal 23 Undang-Undang Nomor 23 Tahun 1999 tentang Bank Indonesia menyatakan bahwa Bank Indonesia dapat mencabut dan menarik uang rupiah dari peredaran dengan memberikan penggantian dengan nilai yang sama.

d. Pasal 65 dan Pasal 66 Undang-Undang Nomor 23 Tahun 1999 tentang Bank Indonesia merumuskan bentuk pelanggaran serta ancaman pidana dan sanksi administratif, yaitu: Dalam Pasal 65 UndangUndang Nomor 23 Tahun 1999 tentang Bank Indonesia menyatakan bahwa:

"Barang siapa dengan sengaja melakukan pelanggaran atas ketentuan sebagaimana dimaksud dalam Pasal 2 ayat (3), diancam dengan 
PRESUMPTION of LAW

Fakultas Hukum Universitas Majalengka

pidana kurungan sekurang-kurangnya 1 (satu) bulan dan paling lama 3 (tiga) bulan, serta denda sekurang-kurangnya Rp2.000.000,00 (dua juta rupiah) dan paling banyak Rp6.000.000,00 (enam juta rupiah)". Dalam Pasal 65 Undang-Undang Nomor 23 Tahun 1999 tentang Bank Indonesia menyatakan bahwa :

"Barang siapa dengan sengaja melakukan pelanggaran ketentuan sebagaimana dimaksud dalam Pasal 2 ayat (4), diancam dengan pidana penjara sekurang-kurangnya 1 (satu) tahun dan paling lama 3 (tiga) tahun, serta denda sekurang-kurangnya Rp1.000.000.000,00 (satu miliar rupiah) dan paling banyak Rp3.000.000.000,00 (tiga miliar rupiah)".

e. Pasal 2 Ayat (2) Undang-Undang Nomor 24 Tahun 1999 tentang Lalu Lintas Devisa dan Sistem Nilai Tukar yang mengatur penggunaan devisa untuk keperluan transaksi dalam negeri, wajib memperhatikan ketentuan mengenai alat pembayaran yang sah sebagaimana diatur dalam Undang-Undang BI.

2. KUHP dalam Bab $X$ tentang pemalsuan mata uang dan uang kertas pada Pasal- Pasal 244 s.d 252 KUHP yang mengatur delik kejahatan terhadap mata uang dan ancaman pidana,

3. Pasal 36 Undang-Undang Republik Indonesia Nomor 7 Tahun 2011 Tentang Mata Uang

Undang-Undang No. 7 Tahun 2011 tentang Mata Uang, mengatur dan mengancam pidana terhadap pelaku kejahatan pemalsuan Mata Uang Rupiah sebagaimana diatur dalam Pasal 36 KUHP maupun Undang-Undang No. 7 Tahun 2011 sama-sama mengatur dan mengancam pidana terhadap kejahatan pemalsuan mata uang, dan sejumlah prinsip Hukum Pidana dalam KUHP tetap berlaku baik terhadap tindak pidana menurut Undang-Undang No. 7 Tahun 2011 tentang Mata Uang maupun berdasarkan ketentuan KUHP yaitu pada Pasal 244 KUHP dan Pasal 245 KUHP $^{9}$.

Pasal 244 dan Pasal 245 KUHP merupakan titik sentral pengaturan dan pembahasan tentang pemalsuan dan peredaran uang sebagai tindak pidana yang berkaitan dengan otoritas Negara dan Bank Indonesia di bidang mata uang atau uang kertas maupun Mata Uang Rupiah.

Gabungan antara ketentuan Pasal 244 KUHP dengan Pasal 245 KUHP kemudian dijadikan Pasal 36 Undang-Undang No. 7 Tahun 2011 tentang Mata Uang. Perbedaan berikutnya ialah pemalsuan mata uang dan/atau uang kertas menurut Pasal 244 KUHP dan Pasal 245 KUHP, hanya ditujukan pada mata uang dan/atau uang kertas Negara atau Bank, sedangkan menurut UndangUndang No. 7 Tahun 20112011 tentang Mata Uang secara tegas disebutkan dengan Mata Uang Rupiah. UndangUndang No. 7 Tahun 2011 tidak lagi menyebutkan mata uang negara atau uang kertas bank, melainkan hanya menyebutkan sebagai Mata Uang Rupiah. Pasal 36 ayat-ayatnya dari Undang-Undang No. 7 Tahun 2011 secara tegas menyebutkan "memalsu

\footnotetext{
${ }^{9}$ Ibid
} 
PRESUMPTION of LAW

Fakultas Hukum Universitas Majalengka

Volume 3 Nomor 2 Oktober 2021

Rupiah" (ayat 1), "Rupiah Palsu" (ayat 2), "Rupiah Palsu" (ayat 3), "Rupiah Palsu" (ayat 4), Rupiah Palsu" (ayat 2), (ayat 5). Dalam UndangUndang No. 7 Tahun 2011 tentang Mata Uang, juga dirumuskan bahwa "Rupiah Palsu adalah suatu benda yang bahan, ukuran, warna, gambar dan/atau desainnya menyerupai Rupiah yang dibuat, dibentuk, dicetak, digandakan, atau diedarkan, tidak digunakan sebagai alat pembayaran dengan merendahkan kehormatan Rupiah sebagai simbol negara". (Pasal 1 Angka 8). Perihal tindak pidana "Meniru" atau "Memalsu" mata uang menurut Pasal 244 KUHP, dijelaskan oleh Adami Chazawi dan Ardi Ferdian dikemukakan bahwa perbuatan meniru (namaken) adalah membuat sesuatu yang menyerupai atau seperti yang asli dari sesuatu tersebut.

KUHP pada Pasal 244 dan Pasal 245 KUHP, menekankan objek ditiru dan/atau dipalsukan dan diedarkan kepada masyarakat ialah mata uang atau uang kertas yang dikeluarkan oleh Negara atau Bank, sedangkan UndangUndang No. 7 Tahun 2011 menekankan bahwa yang ditiru dan/atau dipalsukan itu ialah Mata Uang Rupiah. Perbedaan kedua pengaturan tersebut merupakan bagian dan contoh dari keberadaan KUHP yang sudah lama diberlakukan sebagai produk hukum warisan kolonial, sementara Undang-Undang No. 7 Tahun 2011 adalah produk hukum nasional yang relatif baru.

Unsur kesalahan dalam kejahatan peniruan dan pemalsuan mata uang dan uang kertas Negara maupun uang kertas bank sebagaimana yang dirumuskan dalam Pasal 244 KUHP adalah kesengajaan dengan maksud berupa kesalahan dalam arti yang sempit. Pelaku dalam melakukan perbuatan meniru dan memalsu mata uang atau uang kertas yang dikeluarkan oleh Negara atau bank didorong oleh suatu tujuan yang bermaksud mengedarkan atau menyuruh orang lain mengedarkan uang kertas palsu atau uang kertas tidak asli tersebut sebagai mata uang atau uang kertas asli dan tidak palsu demi memperoleh suatu keuntungan ${ }^{10}$. Berdasarkan kepada Pasal 245 KUHP yang menyatakan:

"Barangsiapa dengan sengaja mengedarkan mata uang atau uang kertas yang dikeluarkan oleh negara atau bank sebagai mata uang atau uang kertas yang tulen atau tidak palsu, padahal ditiru atau dipalsu oleh sendirinya, atau waktu diterimanya diketahui bahwa tidak tulen atau palsu, ataupun barangsiapa menyimpan atau memasukkan ke Indonesia, mata uang dan uang kertas yang demikian, dengan maksud mengedarkan sebagai uang tulen dan tidak palsu, diancam dengan pidana penjara paling lama lima belas tahun".

Rumusan pada Pasal 245 KUHP tersebut, ada 4 bentuk penjelasan kejahatan pengedaran uang palsu, yaitu: ${ }^{11}$

${ }^{10}$ Recky V. Ilat, Kajian Pasal 245 Kuhp Tentang Mengedarkan Uang Palsu Kepada Masyarakat, Jurnal, Lex Crimen Vol. V/No. 5/Jul/2016, Fakultas Hukum Unsrat, hlm 80 https://media.neliti.com/media/publications/146277-ID-kajian-pasal-245-kuhp-tentang

mengedarka.pdf, diakses pada tanggal 28 Juni 2021

${ }^{11}$ Ibid 
PRESUMPTION of LAW

Fakultas Hukum Universitas Majalengka

Volume 3 Nomor 2 Oktober 2021

1. Melarang orang yang dengan sengaja mengedarkan mata uang atau uang kertas negara atau uang kertas bank palsu yang seolah-olah sebagai mata uang kertas asli dan tidak dipalsu, yang mana mata uang palsu tersebut ditiru atau dibuat sendiri oleh yang bersangkutan.

2. Melarang orang yang menerima dan mengetahuinya mata uang atau uang kertas negara atau uang kertas bank tersebut palsu, lalu dengan sengaja mengedarkannya sebagai mata uang atau uang kertas asli dan tidak dipalsu.

3. Melarang orang yang dengan sengaja menyimpan mata uang atau uang kertas palsu lalu memasukkan ke Indonesia, yang mana mata uang atau uang kertas palsu tersebut ditiru atau dibuat oleh sendirinya lalu bertujuan untuk mengedarkan atau menyuruh orang lain mengedarkan mata uang atau uang kertas palsu tersebut seolah-olah mata uang atau uang kertas asli.

4. Melarang orang yang mendapat mata uang atau uang kertas palsu lalu dengan sengaja menyimpan lalu memasukkannya ke Indonesia, dengan maksud mengedarkan atau menyuruh orang lain untuk mengedarkannya sebagai mata uang atau uang kertas asli.

Objek kejahatan dalam Pasal 245 KUHP adalah sama dengan objek kejahatan dalam Pasal 244 KUHP, yakni:

1. Mata Uang;

2. Uang Kertas; dan

3. Uang Kertas Bank.

Pada Pasal 244 KUHP unsur perbuatan yang dilarang adalah meniru dan memalsu, sedangkan pada Pasal 245 KUHP unsur perbuatan yang dilarang adalah mengedarkan, menyimpan, dan memasukkan ke Indonesia. Menurut ketentuan pada Pasal 244 dan 245 KUHP tersebut, kejahatan pada Pasal 245 KUHP terjadi setelah terjadinya kejahatan pada Pasal 244 KUHP.

Pelaku biasanya terlebih dahulu meniru dan memalsu mata uang atau uang kertas sebelum diedarkan atau menyimpan uang palsu tersebut. Perbuatan meniru menghasilkan mata uang dan uang kertas tidak asli, sedangkan perbuatan memalsu menghasilkan mata uang dan uang kertas dipalsu. Kedua uang yang mengandung sifat demikian dapat disebut uang palsu. Setelah adanya mata uang atau uang kertas palsu barulah dapat dilakukan perbuatan mengedarkan, menyimpan dan memasukkan ke Indonesia. Biasanya tindak pidana pengedaran uang palsu dilakukan oleh lebih dari satu orang pelaku atau bersama-sama.

Di dalam kitab Undang-undang hukum pidana sebagai landasan hukum setiap tindak pidana di Indonesia, melarang diedarkan dan dipergunakannya benda-benda yang palsu antara lain mata uang palsu, sehingga peredarannya dan penggunaannya dianggap tidak sah dan merupakan suatu tindak pidana penipuan kepada masyarakat. Dengan demikian adalah hal yang positif, jika setiap orang yang mendapatkan dan memiliki mata uang palsu untuk segera melaporkan dan menyerahkannya ke pihak yang berwenang serta diselesaikan menurut prosedur hukum yang berlaku. 
PRESUMPTION of LAW

Fakultas Hukum Universitas Majalengka

\section{Hambatan Dalam Penegakan Hukum Terhadap Pelaku Penyebaran dan Penyimpanan Uang Rupiah Palsu}

Pelaksanaan penegakan hukum khususnya terhadap pelaku penyebaran dan penyimpanan uang rupiah palsu yang dilakukan oleh Polisi mempunyai beberapa permasalahan yang merupakan suatu hambatan. Hambatan secara internal yang dihadapi oleh Polri selaku penyidik dalam pemberantasan pemalsuan mata uang terutama pada proses penyidikan dapat diartikan yaitu hambatan yang menyangkut aspek legal formal yang menjadi dasar kewenangan yang diberikan serta tata cara bekerjanya keseluruhan instansi-instansi penegak hukum untuk membuktikan telah terjadinya pemalsuan mata uang terutama pelaku secara terorganisir (organized crime). Hambatan yang bersifat kelembagaan instansi aparat penegak hukum (law enforcement officer) yang meliputi: ${ }^{12}$

a Kurangnya koordinasi antar aparat penegak hukum (law enforcement officer)

b Sumber daya Manusia (Human resources). Rendanya mental aparat penegak hukum (law enforcement officer).

c Lemahnya penyidikan terhadap pelaku yang dikategorikan sebagai pelaku yang menyuruh melakukan dan pengungkapan jaringan peredaran pemalsuan mata uang pada sistem pembuktian. Dalam hukum pidana mengenal klasifikasi peran dari masing-masing pelaku pada suatu perbuatan pidana antara lain: ${ }^{13}$

1). dader.

2). Mededader

3).medepleger,

4).doen pleger..

5). uitlokker:

e Penyidikan yang dilakukan oleh penyidik saat ini hanya sebatas pelaku yang mengedarkan mata uang palsu sehingga kesulitan dalam pemenuhan unsur subjektif yakni mens rea. Masalah pembuktian bagi penyidik merupakan suatu tindakan refresif (sarana penal dalam kebijakan hukum pidana) terhadap pelaku kejahatan di dasarkan pada unsur subjektif atau mens rea dan unsur objektifnya atau actus reus. Mens rea yang harus dibuktikan yaitu knowledge (mengetaui atau patut menduga) dan intended (bermaksud). Hasil berkas penyidikan pemalsuan uang baru dapat diajukan ke Kejaksaan apabila lengkap disertai dengan barang bukti. Biasanya kejahatan pemalsuan mata uang terbukti secara tertangkap tangan, oleh karena itu barang bukti selalu dapat disertakan secara lengkap dalam berkas, disertai pengakuan para tersangka. Oleh karena itu dakwaan disusun tidak terlalu rumit, bahkan hampir sama dengan perkara sumir. Dengan demikian hukum acara pembuktian

${ }^{12}$ Ronald F. C. Sipayung Alvi Syahrin, Suhaidi, Mahmud Mulyadim, Analisis Yuridis Peran Polri Dalam Penanggulangan Tindak Pidana Pemalsuan Mata Uang Terkait Dengan Undang-Undang Nomor 7 Tahun 2011 Tentang Mata Uang, USU Law Journal, Vol.4.No.3(Juni 2016) hlm 168

${ }^{13}$ Ibid 
PRESUMPTION of LAW

Fakultas Hukum Universitas Majalengka

Volume 3 Nomor 2 Oktober 2021

dimuka pengadilan menjadi mudah, sehingga ada anggapan bahwa di dalam persidangan pemeriksaan kepada terdakwa tidak perlu dikembangkan kepada hal-hal lain, selain kepada unsur-unsur Pasal yang didakwakan.

Hambatan eksternal yang dialami dalam kerangka penanggulangan pemalsuan mata antara lain ${ }^{14}$ :

a Belum optimalnya koordinasi dan langkah proaktif dengan Badan Koordinasi Pemberantasan Rupiah Palsu (Botasupal).

b Belum efektifnya sistem pemidanaan dalam kerangka pertanggungjawaban pidana yang dilakukan oleh sistem peradilan pidana terhadap pelaku pemalsuan mata uang agar efektifnya penjeraan..

c Dalam kasus-kasus tergambar bahwa pelaku bukan dari kalangan ekonomi lemah atau kelas bawah, tetapi dilakukan oleh orang-orang dengan status sosial yang cukup baik, berpendidikan, dan dari tingkat pergaulan yang layak. Di dalam penyidikan, penuntutan dan pemeriksaan persidangan tidak pernah diungkapkan apakah terdakwa seorang residivis atau bukan. Pengakuan terdakwa "pernah membuat uang palsu" seharusnya dikembangkan.

d Dalam kasus-kasus pemalsuan uang dan pengedaran uang palsu, Jaksa Penuntut Umum dengan tepat dan benar menerapkan ajaran penyertaan dengan mendakwakan Pasal 55 ayat (1) ke 1. Belum tertangkapnya beberapa pelaku lain, mengindikasikan kemungkinan adanya pengajur pembuatan uang palsu atau pengedaran uang palsu, yang memungkinkan diterapkannya Pasal 55 ayat (2).

\section{Upaya Pemerintah Dalam Mengatasi Masalah Penyebaran Uang Palsu}

Pemerintah Indonesia saat ini telah meratifikasi konvensi internasional mengenai Pemberantasan Uang Palsu Beserta Protokol (International Convention for the Suppression of Counterfeiting Currency and Protocol, Geneve 1929). Selain itu Presiden Republik Indonesia mengeluarkan Peraturan Presiden Nomor 123 Tahun 2012 tentang Badan Koordinasi Pemberantasan Rupiah Palsu (PP Botasupal). Fungsi dari Badan Koordinasi Pemberantasan Rupiah Palsu (Botasupal) yaitu sebagai koordinator dalam hal pemberantasan uang palsu yang memadukan kegiatan dan operasi pemberantasan rupiah palsu yang dilakukan oleh lembaga/instasi terkait sesuai dengan fungsi, tugas, dan wewenang masing-masing lembaga/instasi. Tugas dari Botasupal yaitu mengoordinasikan dan mensinkronisasikan penyusunan kebijakan pemberantasan uang palsu, mengoordinasikan dan mensinkronisasikan pelaksanaan pemberantasan rupiah palsu, menganalisis dan mengevaluasi pemberantasan rupiah palsu, memfasilitasi kerja sama pelaksanaan pemberantasan rupiah palsu, membuat dan memberikan rekomendasi kepada lembaga/instansi terkait mengenai pemberantasan rupiah palsu, dan menghimpun data dan bahan keterangan yang terkait

\footnotetext{
${ }^{14}$ Ibid, hlm 170
} 
PRESUMPTION of LAW

Fakultas Hukum Universitas Majalengka

Volume 3 Nomor 2 Oktober 2021

dengan pemberantasan rupiah palsu. Dengan adanya Botasupal ini diharapkan dapat memberantas pengedaran uang palsu di Indonesia. ${ }^{15}$

BI juga berperan dalam pemberantasan uang palsu di Indonesia, yaitu dengan membentuk suatu lembaga yang dapat mendeteksi keberadaan uang palsu yang bernama Bank Indonesia Counterfait Analysis Center (BI-CAC). Adapun tujuan dari pembentukan BI-CAC ini yaitu untuk memudahkan Botasupal atau pihak kepolisian untuk membongkar jaringan pemalsu uang. Hal ini mengingat jaringan pembuat dan pengedar uang palsu di Indonesia cukup besar. Upaya-upaya ini merupakan upaya yang diterapkan oleh Pemerintah dan juga Lembaga/Instansi yang berkaitan dengan uang di Indonesia, akan tetapi pelaksanaan dari pemberantasan pengedaran uang palsu di Indonesia belum efektif oleh karena itu perlu ada upaya lain yang dapat secara efektif memberantas pengedaran uang palsu di Indonesia.

Upaya lain yang dilakukan dalam kerangka penanggulangan pemalsuan mata uang, maka langkah-langkah yang dilakukan antara lain: ${ }^{16}$

a. Penanggulangan kejahatan uang palsu yang dilakukan oleh Polri, yang dalam pelaksanaannya, meminta bantuan kepada Bank Indonesia sebagai Bank Central dan pihak Kejaksaan.

b. Berdasarkan Inpres Nomor. 1 tahun 1971, maka Botasupal dapat mengkoordinasikan dengan instansi-instansi penegak hukum lainnya, guna kepentingan kegiatan operasi dan pembinaan, baik diluar maupun di dlm negeri dalam menanggulangi tindak pidana upal, namun dalam penyidikan uang palsu sesuai Undang-Undang Nomor 8 Tahun 1981 tentang KUHAP tetap merupakan tugas mandiri dari penyidik polri.

c. Kerjasama kepolisian baik regional maupun internasional dapat dilakukan melalui interpol, badan-badan pemerintah lainnya atau secara langsung.

d. Cara yang dilakukan untuk penanganan pengambilan dan pengumpulan barang bukti antara lain:

1).Jangan terjadi kerusakan, yang timbul akibat kecerobohan cara mengambil, mengumpul dan penyimpanannya.

2). Jangan dilipat (menambah lipatan).

3). Jangan melakukan coret-coretan atau tanda lainnya pada uang palsu tersebut.

4). Apabila hendak memberi tanda dan kode, diberikan pada sampul di mana uang palsu tersebut disimpan.

5). Sedapat mungkin ambil barang bukti uang palsu dengan menggunakan sarung tangan dan pegang pada bagian yang diperkirakan tidak ada sidik jari orang lain pada uang palsu yang tercampur (diselang-selingi) dengan uang asli.

6).Pada uang palsu yang terbakar seluruh atau sebagian

${ }^{15}$ Denico Doly, Tindak Pidana Pengedaran Uang Palsu Di Indonesia, Info Singkat (C) 2009, Pusat Pengkajian, jurnal Pengolahan Data dan Informasi (P3DI), Sekretariat Jenderal DPR RI, ISSN 2088-2351, Vol. V, No. 09/I/P3DI/Mei/2013,

${ }^{16}$ Hasil wawancara dengan penyidik pada Subdit Tipiter Direktorat Reserse Kriminal Khusus Polres Majalengka, tanggal 25 Mei 2021 
PRESUMPTION of LAW

Fakultas Hukum Universitas Majalengka

Volume 3 Nomor 2 Oktober 2021

7).Pengambilan dan pengumpulan barang bukti uang palsu berupa alat dan bahan pembuat uang palsu antara lain bekas-bekas cat pada alat pembuat uang palsu seperti pada mesin cetak dan acuan cetak jangan sampai hilang.

8). Temuan uang palsu oleh perbankan harus diperoses oleh Bank Indonesia dan dilaporkan kepada Polri.

\section{G.Kesimpulan}

1. Proses penegakan hukum terhadap pelaku penyebaran dan penyimpanan uang rupiah palsu di Kabupaten Majalengka dilaksanakan oleh aparat penegak hukum mulai dari kepolisian, kejaksanaan dan pengadilan, sesuai dengan tahapan sistem peradilan pidana di Indonesia, yang bertujuan menjatuhkan pidana terhadap pelaku tindak pidana pemalsuan uang dan mencegah serta menanggulangi masyarakat menjadi korban pemalsuan uang, menyelesaikan kasus kejahatan dan menimbulkan efek jera bagi pelaku tindak pidana dan penyimpanan uang rupiah palsu. Sanksinya adalah penjara paling lama 15 (lima belas) tahun dan pidana denda paling banyak Rp 50.000.000.000,00 (lima puluh miliar rupiah) sesuai dengan Pasal 36 ayat (3) Undang-Undang No. 7 Tahun 2011 tentang Mata Uang dan bisa juga dikenakan sanksi penjara selama-lamanya lima belas tahun sesuai dengan ancaman pada Pasal 244 dan 245 KUHP

2. Hambatan yang ditemukan dalam penanggulangan pemalsuan mata uang dibagi atas hambatan internal dan hambatan eksternal. Hambatan internal antara lain: Pertama, kurangnya koordinasi antar aparat penegak hukum (law enforcement officer) di lapangan menyangkut pembuktian tindak pidana pemalsuan mata uang terutama terhadap pelaku yang dikategorikan sebagai organized crime. Kedua, lemahnya penyidikan terhadap pelaku yang dikategorikan sebagai pelaku yang menyuruh melakukan dan pengungkapan jaringan peredaran pemalsuan mata uang pada sistem pembuktian. Ketiga, penyidikan yang dilakukan oleh penyidik saat ini hanya sebatas pelaku yang mengedarkan mata uang palsu sehingga kesulitan dalam pemenuhan unsur subjektif yakni mens rea. Hambatan secara eksternal yakni: Pertama, belum optimalnya koordinasi dan langkah proaktif dengan Badan Koordinasi Pemberantasan Rupiah Palsu (Botasupal). Kedua, belum efektifnya sistem pemidanaan dalam kerangka pertanggungjawaban pidana yang dilakukan oleh sistem peradilan pidana terhadap pelaku pemalsuan mata uang agar efektifnya penjeraan.

3. Upaya yang dilakukan dalam memberantas uang palsu sudah diterapkan oleh Pemerintah maupun BI, akan tetapi upaya ini belum dapat secara maksimal dapat memberantas pengedaran uang palsu. Oleh karena itu perlu adanya penegakan hukum yang tegas dalam memberantas uang palsu dan menerapkan teknologi pembuatan uang yang tidak bisa diterapkan oleh pihak lain, selain bank sentral. 
PRESUMPTION of LAW

Fakultas Hukum Universitas Majalengka

Volume 3 Nomor 2 Oktober 2021

\section{H. Saran}

1. Diharapkan kepada penegakan hukum untuk melakukan Sosialisasi kepada masyarakat agar dapat membedakan antara uang palsu dengan uang asli dan bergegas melaporkannya apabila kedapatan melihat pelaku tindak pidana pemalsuan uang dan peredarannya pada pihak yang berwajib.

2. Diharapkan untuk mengatasi hambatan Polri dalam Penyebaran dan Penyimpanan Uang Rupiah Palsu adalah adanya koordinasi secara terintegrasi dengan instansi terkait baik dalam kerangka pengungkapan maupun penyelidikan. Untuk terintegrasinya koordinasi diperlukan pembentukan tim terpadu dalam penanggulangan pemalsuan mata uang. Instansi dimaksud yakni Polri, Kejaksaan, Badan Koordinasi Pemberantasan Rupiah Palsu (Botasupal), PERURI, Bank Indonesia dan jajaran Intelijen Negara.

3. Diharapkan kepada masyarakat, ketika menerima uang palsu masyarakat dihimbau untuk tidak membelanjakan uang palsu yang diterima, menyampaikan uang palsu yang diterima ke Bank atau Bank Indonesia terdekat untuk permohonan klarifikasi, dan melaporkan dugaan tindak pidana pemalsuan uang ke aparat penegak hukum terdekat. Selalu waspada dan meluangkan untuk memeriksa keaslian uang rupiah yang diterima dengan cara 3D (dilihat, diraba, ditrawang). 


\section{DAFTAR PUSTAKA}

\section{A. Buku}

Adami Chazawi, Kejahatan Mengenai Pemalsuan, Raja Grafindo Persada, Jakarta, 2005.

Andi Hamzah, Hukum Acara Pidana Indonesia, Sinar Grafika, Jakarta, 2011.

Barda Nawawi Arief, Kebijakan Hukum Pidana, Citra Aditya Bakti, Bandung, 2002.

Chairul Huda, Dari Tiada Pidana Tanpa Kesalahan Menuju Kepada Tiada Petanggung Jawaban Pidana Tanpa Kesalahan, Kencana, Jakarta, 2008.

Eddi Wibowo, Hukum dan Kebijakan Publik, YPAPI, Yogyakarta. 2004.

Moeljatno, Asas-asas Hukum Pidana, Putra Harsa, Surabaya, 1993.

PAF Lamintang, Dasar-Dasar Hukum Pidana Indonesia, Sinar Baru, Bandung, 1997.

Soerjono Soekanto, Faktor-faktor Yang Mempengaruhi Penegakan Hukum, UI Pres, Jakarta, 1983.

, Pengantar Penelitian Hukum, UI Press, Jakarta, 2008.

Solikin Suseno, Uang, Pengertian, Penciptaan, dan Peranannya dalam Perekonomian, Bank Indonesia, Jakarta , 2005.

\section{B. Peraturan Perundang-undangan}

Undang-Undang Dasar Negara Republik Indonesia Tahun 1945.

Undang-Undang Nomor 1 Tahun 1946 Tentang Kitab Undang-Undang Hukum Pidana

Undang-Undang Nomor 2 Tahun 2002 tentang Kepolisian

Undang-Undang Nomor 7 Tahun 2011 Tentang Mata Uang

Peraturan Kepala Kepolisian Republik Indonesia Nomor 23 Tahun 2010 tentang Susunan Organisasi dan Tata Kerja pada Tingkat Polres dan Polsek.

\section{Sumber Lain}

Ailul Afilah, Tinjauan Yuridis Terhadap Putusan Hakim Dalam Tindak Pidana Penganiayaan, Mengakibatkan Matinya Seseorang Yang Dilakukan Oleh Anggota Polri (Studi Kasus Di Pengadilan Negeri Surakarta), 
Fakultas Hukum Universitas Muhammadiyah Surakarta 2009, hlm 1, http://eprints.ums.ac.id/4221/1/C100040036.pdf diakses pada tanggal 28 Juni 2021

Akhmad Ulil Manafi, Analisis Hukum Islam Terhadap Pembuktian Hasil Tes Dna Dalam Sumpah Lian Terkait Penentuan Nasab Anak, Skripsi, Universitas Islam Negeri Sunan Ampel Fakultas Syari'ah Dan Hukum Jurusan Hukum Perdata Islam Prodi Hukum Keluarga Islam (Ahwal AsSyakhsiyah) Surabaya 2017, HLM 17 http://digilib.uinsby.ac. id/18288/6/Bab\%202.pdf, diakses Pada tanggal 28 Juni 2021

Bustaman, Konsep Uang Dan Peranannya Dalam Sistem Perekonomian Islam ( Studi Atas Pemikiran Muhammad Abdul Mannan ), Skripsi, Fakultas Ekonomi Dan Bisnis Islam Uin Alauddin Makassar 2016, hlm 16

Denico Doly, Tindak Pidana Pengedaran Uang Palsu Di Indonesia, Info Singkat (C) 2009, Pusat Pengkajian, jurnal Pengolahan Data dan Informasi (P3DI), Sekretariat Jenderal DPR RI, ISSN 2088-2351, Vol. V, No. 09/I/P3DI/Mei/2013,

Eky Rhizky, Tinjauan Yuridis Tindak Pidana Memproduksi Atau Mengedarkan Sediaan Farmasi Yang Tidak Memiliki Izin Edar Dan Memenuhi Standar Farmakope Indonesia (Studi Kasus Putusan No. 09/Pid.Sus/2014/Pn.Pct), Skripsi, Fakultas Hukum Universitas Trisakti Jakarta 2016, hlm 19, http://repository.trisakti.ac.id/usaktiana/ digital/000000000 00000081848/2016_TA_HK_01009164_Bab2.pdf, diakses pada tanggal 28 Juni 2021

Erna Dewi , Penegakan Hukum Terhadap Pelaku Tindak Pidana Pemalsuan Uang Dan Pengedar Uang Palsu Di Kota Bandar Lampung, Keadilan Progresif, Fakultas Hukum Universitas lampung Volume 5 Nomor 1 Maret 2014, hlm 75

Hasaziduhu Moho, Penegakan Hukum Di Indonesia Menurut Aspek Kepastian Hukum, Keadilan Dan Kemanfaatan, Jurnal Warta, Universitas Dharmawangsa, Edisi 59 Januari 2019

I Wayan Bela Siki Layang, Fungsi Dan Peranan Patroli Polisi Dalam Melakukan Penanggulangan Kejahatan (Study Pada Polsek Kuta, Kecamatan Kuta, Kabupaten Badung), Laporan Penelitian, Fakultas Hukum Universitas Udayana Denpasar 2017, hlm 1, http://erepo.unud.ac.id/id/eprint/12393/1/20d02e41493da1f511a07a229 372fe03.pdf, diakses pada tanggal 28 Juni 2021

Insan Normawan Hartanto, Penegakan Hukum Terhadap Tindak Pidana Pemalsuan Uang Dihubungkan Dengan Ketentuan PerundangUndangan. Skripsi, Fakultas Hukum Universitas Pasundan Bandung 2016, hlm 63, http://repository.unpas. ac.id/ 13521/ 4/BAB\%20II.pdf, diakses pada tanggal 28 Juni 2021 
Jofra Pratama Putra, Upaya Polresta Yogyakarta Dalam Penegakan Hukum Tindak Pidana Peredaran Uang Palsu, PenelitianUniversitas Atmajaya Yogyakarta Fakultas Hukum 2011, hlm 3, http://ejournal.uajy.ac.id/690/2/1HK08585.pdf diakses pada tanggal 28 Juni 2021

Kurniawan Muhammad Nur, Dampak Kemiskinan Terhadap Penyimpangan Sosial (Studi Kasus Di Desa Komering Agung Kecamatan Gunung Sugih Kabupatenlampung Tengah), Skripsi, Fakultas Dakwah Dan Ilmu Komunikasi Universitas Islam Negeri Raden Intan Lampung 1439 H/ $2017 \mathrm{M}$, .

Meliyawati, Analisis Kinerja Aparatur Kepolisian Bagian Satuan Reserse Kriminal (Sat Reskrim) Di Unit Pidana Umum (Unit Pidum) Polres Kabupaten Seluma, Jurusan Ilmu Administrasi Negara Fakultas Ilmu Sosial Dan Ilmu Politik Universitas Bengkulu 2014, hlm 50, http://repository.unib.ac.id/9262/1/I\%2CII\%2CIII\%2CI-14-mel-FS.pdf, diakses pada tanggal 28 Juni 2021

Meutia Nadjib, Tinjauan Sosio-Yuridis Terhadap Kejahatan Pengedaran Uang Palsu Yang Dilakukan Oleh Anak (Studi Kasus Di Pengadilan Negeri Makassar), Skripsi, Bagian Hukum Pidana Fakultas Hukum Universitas Hasanuddin Makassar 2013, hlm 40, https://core.ac.uk/download/ pdf/ 25491457.pdf, diakses pada tanggal 28 Juni 2021

Recky V. Ilat, Kajian Pasal 245 Kuhp Tentang Mengedarkan Uang Palsu Kepada Masyarakat, Jurnal, Lex Crimen Vol. V/No. 5/Jul/2016, Fakultas Hukum Unsrat, hlm 80 https://media.neliti.com/media/publications/ 146277-ID-kajian-pasal-245-kuhp-tentang-mengedarka.pdf, diakses pada tanggal 28 Juni 2021

Riswandi Rahmat, Tinjauan Yuridis Terhadap Tindak Pidana Pembunuhan Berencana (Studi Kasus Putusan Nomor: 78/Pid.B/2014/Pn.Mks), Skripsi, Departemen Hukum Pidana Fakultas Hukum Universitas Hasanuddin Makassar 2017.

Robinson, Dekonstruksi Makna Transaksi Dalam Akuntansi: Suatu Pendekatan Idealisme Syariah Islam, Bisnis, Vol. 2, No. 2, Desember 2014, hlm 33, file:///C:/Users/ MINI\%20PC/Downloads/5265-16423-1-SM.pdf diakses pada tanggal 28 Juni 2021

Ronald F. C. Sipayung Alvi Syahrin, Suhaidi, Mahmud Mulyadim, Analisis Yuridis Peran Polri Dalam Penanggulangan Tindak Pidana Pemalsuan Mata Uang Terkait Dengan Undang-Undang Nomor 7 Tahun 2011 Tentang Mata Uang, USU Law Journal, Vol.4.No.3(Juni 2016) hlm 168

Suhendar Herdiyansyah dan Cecep Sutrisna, Penegakan Hukum Terhadap Tindak Pidana Kepabeanan Atas Implikasi Penyelundupan Barang 
Ekspor Dihubungkan Dengan Undang-Undang No 17 Tahun 2006 Tentang Kepabeanan, Vol 17 No 1 (2018): Wacana Paramarta: Jurnal Ilmu Hukum XVII:1:2018, hlm 62, file:///C:/Users/MINI\% 20PC/ Downloads/ 56-Article\%20Text-337-1-10-20200623.pdf diakses pada tanggal 29 Juni 2021

Suwarjo, Penegakan Hukum Dalam Tindak Pidana Pemalsuan Mata Uang Dollar, Vol. 8 no. 1 Maret 2014, hlm 4 https://media.neliti.com/media/ publications/163574-ID-none.pdf, diakses pada tanggal 28 Juni 2021

Ulfa Hidayatunnikmah, Konsep Uang Perspektif Ekonomi Islam, Skripsi, Institut Agama Islam Negeri (Iain) Metro Tahun 1439 H/2018 M,hlm 23 https:// repository. metrouniv.ac.id/ id/eprint/1071/1/ SKRIPSI\% 20UL FA\% 20HIDAYA TUNNI KMAH\% 20NPM.\%20131 04654.pdf, diakses pada tanggal 28 Juni 2021

Winsherly Tan, Wahyudi Warianto, Tinjauan Yuridis Penggunaan Mata Uang Asing Sebagai Alat Pembayaran Dalam Transaksi Di Wilayah Kedaulatan Negara Kesatuan Republik Indonesia (NKRI), Journal of Judicial Review 27 Vol. XVIII No. 1. (2016), hlm 16, http://repository.uib.ac.id/706/5/S-1351084-chapter2.pdf, diakses pada tanggal 28 Juni 2021 